Vol 41 (2016) No 184 349-361

\title{
The Mediator Role of Social Safeness and Pleasure in Relation between Mobbing and Meaning of Work in Academicians
}

\section{Hakan Sarıçam ${ }^{1}$}

\begin{abstract}
Mobbing is the leading problem of organizations in developed countries and it has also become an important issue in Turkey. Especially, mobbing is very common problem in higher education. The main aim of the study is to examine the mediating roles of social safeness and pleasure in the relationship between the meaning of the work and mobbing. The study group was selected by using a convenience sampling (ease of access) and totally 486 university lecturers and faculty members from 58 various universities of Turkey were included in the study. Participants filled in Mobbing Scale, Social Safeness and Pleasure Scale, Work and Meaning Inventory. Pearson product moment correlation analysis and stepwise linear regression analysis techniques were used in order to detect the direction and level of the relationships between parameters since data were normally distributed and Kolmogorov-Smirnov scores of data were insignificant. According to the mediating analysis findings, social safeness and pleasure are the partial reason for the relationship between mobbing and meaning of the work. As the mobbing level increases, the social safeness and pleasure decrease and this decrease also lower the academicians' meaning of work.
\end{abstract}

Keywords

Mobbing (bullying in workplace)

Meaning of work

Social safeness and pleasure

Article Info

Received: 29.12.2015

Accepted: 03.04.2016

Online Published: 27.04 .2016

\section{Introduction}

Faculties of education are the final step of the training of teachers. Quality of this training and its continuation depend on the working conditions, standard of living and good-mood of the academic members. However, academic and administrative staff working in higher education institutions has various problems as in other work places. Mobbing is the leading problem in any workplace. In fact, universities are organizations where the mobbing is most commonly observed according to Gül, İnce, and Özcan (2011). Similarly, Yelgecen Tigrel and Kokalan (2009) claimed that academicians suffer from mobbing, overly. Most common results of mobbing in universities were absenteeism (Khoo, 2010), clinical depression, anxiety disorders (Fogg, 2008), stress (Archibong, Bassey, \& Effiom, 2010), position or profession changes and decreasing working performance (Cabaros \& Rodrigues, 2006). Therefore, alternative approaches are necassarry for lessenning effects of mobbing (Yaman \& Sarıçam, 2015). In this study, meaning of the work, social safeness and pleasure

\footnotetext{
${ }^{1}$ Dumlupinar University, Faculty of Education, Department of Educational Sciences, Turkey, hakan.saricam@dpu.edu.tr
} 
were handled to cope with mobbing. The basic purpose of the study is to examine the mediating roles of social safeness and pleasure in the relationship between the meaning of the work and mobbing.

\section{Mobbing}

Mobbing is the leading problem of organizations in developed countries and it has also become an important issue in Turkey. In fact, Prime Minister Circular was prepared and it was published in the official newspaper (19.03.2011 and 2011/2 circular) since the number of mobbing events and the mobbing victims are currently increasing in each day.

Psychological harassment in work place which is more commonly named as mobbing refers to a set of recurrent and long-term aggressive behaviors towards one or more than one individual at a work place. Mobbing is defined as the decrease in the work performance of victims and deterioration of their health due to these kinds of behaviors (Moayed, Daraiesh, Shell, \& Salem, 2006, pp. 311-326). According to the definition of Leymann (1996), mobbing is harassing other people, creating a front against an individual and applying a psychological terror to others at a work place. When the mobbing concept was first used in 1970s, it referred to a similar figure to the definition of bullying which was composed of physical aggression. However, it was later decided that mobbing is not that simple and it is composed of planned and systematic methods. According to Leymann (1996), these methods were; attacks on communication, attacks on social relationships, attacks on social image, attacks on occupational status and attacks on health status. Tinaz (2006) stated that forms of psychological harassment in the workplace can happen as downward mobbing which performed by a superior/manager towards the employees (vertical mobbing) as well as horizontal mobbing (among colleagues). Mobbing can rarely happen as upward mobbing which is composed of bullying and harassment perpetrated upwards towards managers. Davenport, Distler, and Eliot (1999) specified that the types of mobbing are as isolation, insults, sarcasm, constant negative criticism, work load, job auction, spreading rumors, condemnation, physical violence and sexual harassment. According to Yaman (2009), mobbing has four sub components as 1- humiliation, 2- discrimination, 3communication barriers and 4- sexual harassment.

\section{Meaning of Work}

Positive organizational behavior studies have accelerated upon the positive psychology influenced the organizational psychology (Yaman \& Sarıçam, 2015). Particularly, studies related to the creation of the meaning of the work or assessment of the meaning of the work is quite remarkable (Lips-Wiersma \& Morris, 2009; Steger, Dik, \& Duffy, 2012). The 'work' is an occupation which is the source of a financial profit and the 'work place' is the environment where the work performance is exhibited and the financial profit is obtained (Fryer \& Payne, 1984). The most general statement of the 'meaning' is the response to a question 'Why am I here?' In the psychology literature, 'meaning' has been associated to agreement, conformity, consistency, integrity and it has been examined as meaning of the life (Dennett, 1995; Keltner, 2009; Molden \& Dweck, 2000, 2006; Park \& Folkman, 1997). Frankl (2006, 2014) explained that the 'meaning' is related to the presence, living and mission. Besides, in the study performed by Yalom (1980), it was shown that 'meaning' had three components as; 1 - a system which describes and interprets the live events, 2- an aim or a reason, 3- the integration of the previous and further life. The meaning of the work is derived from the concept of 'meaning of the life' and it is the complement of the meaning of the life (Yaman \& Sarıçam, 2015).

Morin (2008) classified the meaning of the work into three categories based on the above definition; 1-the importance of the work: it is the value, definition and the presentation of the work from the subjective point of view, 2-subjective directives and guidance: to what extend the work and aims guide the behavior of an individual, 3- compliance between the work and an individual: the consistency between the values, expectations and the performance of an individual. Based on these expressions, the work should be valuable; it should direct towards the purposes of an individual and meet the expectations of an individual in order to be meaningful. Steger et al. (2012) stated that the meaning of a work is the answer(s) to the question related to the importance and the value of the work for an individual. 


\section{Social Safeness and Pleasure}

The importance of interpersonal relationships is undeniable in the nature of the human being (Ryan \& Deci, 2000). Establishing and maintaining relationships with other people lie at the basis of human behavior (Pickett, Gardner, \& Knowles, 2004). Being accepted by others, belonging to a group of people and preserving the relationship are the basic needs of a human being as a social presence (Baumeister \& Leary, 1995; Baumeister \& Tice, 1990). Interpersonal relationships not only contribute to the development of the personality but also lead to the shaping of emotions. An individual gives directions to relationships according to these emotions which can be shaped either positively or negatively (Gilbert et al., 2008). Same authors classified positive emotions into three categories such as feel energetic and excited-.comfort and calmness- trust and satisfaction. They emphasized that trust and satisfaction feelings have important roles in the social relationships.

It was explained that the established or non-established relationships between the baby and the "secure base" lead to the development of confidence in infancy (Bartholomew \& Horowitz, 1991; Bowlby, 1982). Gilbert (2005) defined the trust in social relationships as social trust and he emphasized that trust is the key concept in order to initiate, maintain and finalize the relationship. Gilbert (2009) defined the social safeness and pleasure as the commitment of an individual to her/his social world, the sincerity in the relationships and the serenity that is felt in the relationships. Individuals with high social safeness and pleasure experience the low levels of stress, anxiety, fear and depression and their love, life satisfaction and levels of psychological well-being are also high.

\section{The Current Study}

Academics are a profession which mobbing is most frequently observed (Gül et al., 2011). Westhues $(1998,2004,2006)$ and Friedenberg (2008) specified that emotional abuse is observed most commonly in health and higher education organizations. Even though the number of studies related to the mobbing of the academicians in universities has increased (Keashly \& Neuman, 2010; Taylor, 2012, p. 15), there are still less number of studies in Turkey (Erkutlu \& Chafra, 2014). When we consider that academic organizations are the guards of the realities, detectors of new facts, the protector of the community values, the molder of the youth and the pathfinder of the future (Kaya, 1993), faculties of education have important roles in the training of particularly teachers who have effective and crucial roles in the building of the community. Therefore, it is very important to detect the mobbing levels of academicians in these institutions and determine the factors which affect the meaning of the work in order to increase the quality in the higher education organizations. Additionally, Yaman and Sarıçam (2015) found a negative association between the meaning of the work and mobbing. However, to my knowledge, there is no study which can explain the reasons of this relationship. It is thought that the social safeness and pleasure, which have an important role in the formation of social relations (Kelly, Zuroff, Leybman, \& Gilpert, 2012), has also crucial effects on the relationships at work, particularly, organizational commitment (Çolak, Altinkurt, \& Yilmaz, 2014), organizational culture and climate (Kartal, 2016).

The main aim of the study is to examine the mediating roles of social safeness and pleasure in the relationship between the meaning of the work and mobbing. This structure is shown in Figure-1. In line with this aim, the hypotheses can be seen below:

1- There is a negative association between the mobbing and social safeness and pleasure.

2- There is a positive association between the social safeness and pleasure and the meaning of the work.

3- There is a negative association between mobbing and meaning of the work. 


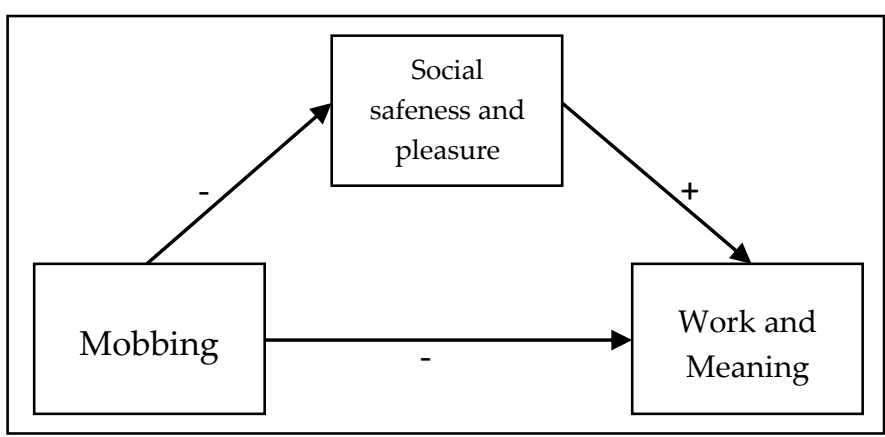

Figure 1. Correlation Model about the Relations between Social Safeness and Pleasure, Mobbing, and Meaning of Work

\section{Method}

\section{Participants}

The study group was selected by using a convenience sampling (ease of access) and totally 486 university lecturers and faculty members in education faculties from 58 differentuniversities of Turkey were included in the study. Participants were from different departments (such as department of educational sciences, department of elementary education, department of Turkish education, and department of computer education and instructional technology) from different areas of expertise. The 183 of participants were female and 303 of them were male. The 63 of them were Prof. Dr., 85 of them were Assoc. Prof., 152 of them were Asst. Prof., 44 of them were Dr., 18 of them were specialist, 18 of them were lecturer, 25 of them were instructor and 81 of them were research assistant. The ages of participants ranged between 25 and 71 and the mean of the age was $42.38(\mathrm{SD}=8.63)$.

\section{Instruments}

Mobing Scale-MS: Mobing Scale was developed by Yaman (2009) for evaluating levels of mobing in work. It consists of 23 items and four sub-scales (humiliation, discrimination, sexual harassment, and communication barriers). These subscales account for the $59.97 \%$ of the total variance. The results of confirmatory factor analysis indicated that 23 items loaded on four factors $\left(\chi^{2}=914.29, \mathrm{~N}=515, \mathrm{df}=220, \mathrm{p}=0.00\right.$; RMSEA=.078, NFI=.95, CFI=.96, IFI=.96, RFI=.94, and SRMR=.074). The values of RMSEA and SRMR up to 0.08 were acceptable (Browne \& Cudeck, 1993; Yaman, 2009). In addition, because of the values of NFI, CFI, IFI, RFI were bigger than 0.90, they had fit index scores (Hu \& Bentler, 1995; Yaman, 2009). The internal consistency reliability coefficients were 91 for humiliation, .77 for discrimination, .79 for sexual harassment, and .79 for communication barriers. Findings also demonstrated that item-total correlations ranged from .54 to .78 . Test-retest reliability coefficients were .78 and .91 for four subscales, respectively.

Social Safeness and Pleasure Scale-SSPS: This scale was developed by Gilbert et al. (2009) and it has 11 statements (e.g., I feel secure and wanted) using a Likert scale from 0 (almost never) to 4 (almost all the time). Turkish adaptation of this scale had been done by Akın, Uysal, Ozkara, and Bingöl (2012). The goodness of fit index values of the model were RMSEA=.048, NFI=.96, CFI=.98, $\mathrm{IFI}=.98$, RFI=.95, GFI=.96, and SRMR=.042. These values had fit index scores (Akin et al., 2012; Hu \& Bentler, 1995). Factor loadings ranged from .41 to .74. The overall internal consistency reliability coefficient of the scale was .82. The corrected item-total correlations of SSPS ranged from .34 to .61.

Work and Meaning Inventory-WAMI: Steger et al. (2012) developed WAMI in order to measure diverse ideas of individual about meaningful work. WAMI consists of ten items and three factors. Akın, Hamedoğlu, Kaya, and Sarıçam (2013) adapted it to Turkish culture. The results of confirmatory factor analysis indicated that 10 items loaded on three factors (positive meaning, meaning making through work, and greater good motivations): $\chi^{2} / \mathrm{df}=2.15, \mathrm{RMSEA}=.087, \mathrm{CFI}=.98$, $\mathrm{IFI}=.98, \mathrm{NFI}=.94, \mathrm{NNFI}=.96, \mathrm{SRMR}=.057$. These values had fit index scores (Akın et al., 2013; Hu \& Bentler, 1995). In the concurrent validity significant relationship $(r=.41)$ was found between total WAMI and the Job Crafting Scale. The internal consistency coefficients of three subscales were .68, .64, 
and .73, respectively. The overall internal consistency coefficient of the scale was .86. Test-retest reliability coefficient was .69. The corrected item-total correlations of WAMI ranged from .30 to .62 . Authors suggested that Turkish version of WAMI should use as one-factor model because three subscales internal consistency coefficients was weak.

\section{Procedure}

Since it is very difficult to reach each of the academicians in all education faculties in Turkey, an internet link was created by researchers which explained the aim of the study and contained the measuring tools. Then, this link was sent to the academicians whose e-mail addresses were available in the websites of universities in Turkey. It was also specified that the application took only 10 minutes of an individual. Data collection took about three months in 2015 academic season. The data were transferred to a package software program. Pearson product moment correlation analysis and stepwise linear regression analysis techniques were used in order to detect the direction and level of the relationships between parameters since data were normally distributed and Kolmogorov-Smirnov scores of data were insignificant. The significance level was accepted as $0.05(\mathrm{p}<0.05)$.

\section{Results}

\section{Correlations and Descriptive Data}

Correlation coefficients of mobbing, social safeness, meaning work standard deviation, average points, Skewness and Kurtosis values are shown in Table 1.

Table 1. Descriptive Statistics, Skewness and Kurtosis Values and Cronbach $\alpha$ Coefficients

\begin{tabular}{|c|c|c|c|c|c|c|c|c|}
\hline Variables & 1 & 2 & 3 & Mean & SD & Skewness & Kurtosis & Cronbach $\alpha$ \\
\hline 1. Mobbing & 1 & & & 48.98 & 22.05 & .66 & -.68 & .81 \\
\hline $\begin{array}{l}\text { 2. Social safeness and } \\
\text { pleasure }\end{array}$ & $-.65^{* *}$ & 1 & & 39.75 & 8.93 & -1.17 & 1.06 & .92 \\
\hline 3. Work and meaning & $-.51^{* *}$ & $.60^{* *}$ & 1 & 27.28 & 10.36 & -.45 & -.51 & .91 \\
\hline
\end{tabular}

As seen in the Table 1, mobing has negative relationships with social safeness and meaning of work $(r=-.65 ;-.51)$. While coefficient of relationship between social safeness and meaning of work is seen as $r=.60$; relatively in $\mathrm{p}<.01$ significance level. That is to say, there is a positive relation between social safeness and meaning of work.

Testing the Mediating Role of Social Safeness and Pleasure in the Relationship between Mobbing and Meaning of Work

Meditation analysis is used to clarify how and why there is a link between two elements. The most prominent procedure to apply this analysis is that dependent, independent and mediator elements should be associated to each other (Kenny, Korchmaros, \& Bolger, 2003). In the Table 1 this procedure is fulfilled. Next levels are as follows:

1. Independent element should forecast dependent element significantly.

2. Independent element should forecast mediator element significantly.

3. Mediator element should forecast dependent variable by its own.

4. While independent and mediator elements statistically forecast dependent element significantly, independent element's coefficient of forecast of dependent element by its own should grow less (MacKinnon, 2008; MacKinnon, Warsi, \& Dwyer, 1995).

For the first procedure of mediating test, meaning of work is taken as dependent element and mobbing is taken as independent element; and basic linear regression analysis is applied. The results are shown in the Table 2. 
Table 2. Mobbing and Meaning of Work

\begin{tabular}{|c|c|c|c|c|c|c|c|}
\hline \multirow[t]{2}{*}{ Variables } & \multicolumn{2}{|c|}{ Unstandardized Coefficients } & \multicolumn{5}{|c|}{$\begin{array}{l}\text { Standardized } \\
\text { Coefficients }\end{array}$} \\
\hline & B & SЕв & $\beta$ & $\mathbf{t}$ & $\mathbf{R}$ & $R^{2}$ & $\mathbf{F}$ \\
\hline Mobbing & -.21 & .016 & -.51 & $-12.99^{*}$ & .51 & .26 & $168.92^{*}$ \\
\hline
\end{tabular}

${ }^{*} p<.001$

As seen in the Table 2, mobbing statistically forecast meaning of work significantly in negative aspect and explains $26 \%$ of total variance of meaning of work $(\beta=-.51, t=-12.99, p<0.001)$.

For the second procedure of mediating test, mobbing is taken as independent element and mediator element social safeness and pleasure is taken as the dependent element; and basic linear regression analysis is applied. The results are shown in Table 3.

Table 3. Mobbing and Social Safeness

\begin{tabular}{llllllll}
\hline Variables & \multicolumn{2}{l}{ Unstandardized Coefficients } & \multicolumn{2}{l}{$\begin{array}{l}\text { Standardized } \\
\text { Coefficients }\end{array}$} & & & \\
& B & SEв & $\boldsymbol{\beta}$ & $\mathbf{t}$ & $\mathbf{R}$ & $\boldsymbol{R}^{2}$ & $\mathbf{F}$ \\
\hline Mobbing & -.30 & .016 & -.65 & $-18.75^{*}$ & .65 & .42 & $351.59^{*}$ \\
\hline$x_{*}<001$ & & & & & & &
\end{tabular}

${ }^{*} p<.001$

As seen in the Table 3, mobbing statistically forecast social safeness and pleasure significantly in negative aspect and explains $42 \%$ of total variance of social safeness and pleasure $(\beta=-.65, t=18.75$, $\mathrm{p}<0.001)$.

For the third procedure of mediating test, mediator element social safeness and pleasure is taken as independent element; and also, meaning of work is taken as the dependent element; and basic linear regression analysis is applied. The results are shown in Table 4.

Table 4. Social Safeness and Meaning of Work

\begin{tabular}{|c|c|c|c|c|c|c|c|}
\hline \multirow[t]{2}{*}{ Variables } & \multicolumn{2}{|c|}{ Unstandardized Coefficients } & \multicolumn{5}{|l|}{$\begin{array}{l}\text { Standardized } \\
\text { Coefficients }\end{array}$} \\
\hline & B & SEв & $\beta$ & $\mathbf{t}$ & $\mathbf{R}$ & $R^{2}$ & $\mathbf{F}$ \\
\hline $\begin{array}{l}\text { Social safeness } \\
\text { and pleasure }\end{array}$ & .52 & .031 & .60 & $16.64^{*}$ & .60 & .36 & $276.74^{*}$ \\
\hline
\end{tabular}

As seen in the Table 4, social safeness and pleasure statistically forecast work and meaning significantly in positive aspect and explains $36 \%$ of total variance of work and meaning $(\beta=.60, \mathrm{t}=$ 16.64, $\mathrm{p}<0.001)$.

For the last procedure of mediating test, mediator element social safeness and mobbing are taken as independent elements; and also, work and meaning is taken as the dependent element; and stepwise regression analysis is applied. The results are shown in Table 5. 
Table 5. Mediation of Social Safeness and Pleasure in Link between Mobbing and Meaning of Work: Stepwise Regression Analysis with Dependent Element Meaning of Work

\begin{tabular}{|c|c|c|c|c|c|c|c|}
\hline \multirow[t]{2}{*}{ Variables } & \multicolumn{2}{|c|}{ Unstandardized Coefficients } & \multicolumn{5}{|l|}{$\begin{array}{l}\text { Standardized } \\
\text { Coefficients }\end{array}$} \\
\hline & B & SЕв & $\beta$ & $\mathbf{t}$ & $\mathbf{R}$ & $R^{2}$ & $\mathbf{F}$ \\
\hline Step1 Mobbing & -.21 & .016 & -.51 & $-12.99^{*}$ & .51 & .26 & $168.92^{*}$ \\
\hline Step2 Mobbing & -.08 & .019 & -.20 & $-4.33^{*}$ & & & \\
\hline Social safeness & .41 & .040 & .47 & $10.08^{*}$ & .62 & .39 & $152.83^{*}$ \\
\hline
\end{tabular}

${ }^{*} p<.001$

As seen in the Table 5, changes in the independent elements (mobbing and social safeness) can explain 39\% of the change in dependent variable (work and meaning). ANOVA test show the model as significant $(\mathrm{F}=152.83 ; \mathrm{p}<0.001)$. Independent variable (mobbing) contributes more to the explanation of the model in terms of $\beta$ values $\left(\mathrm{R}^{2}=.39\right)$. The change in $\beta$ values are shown in the Figure 2.

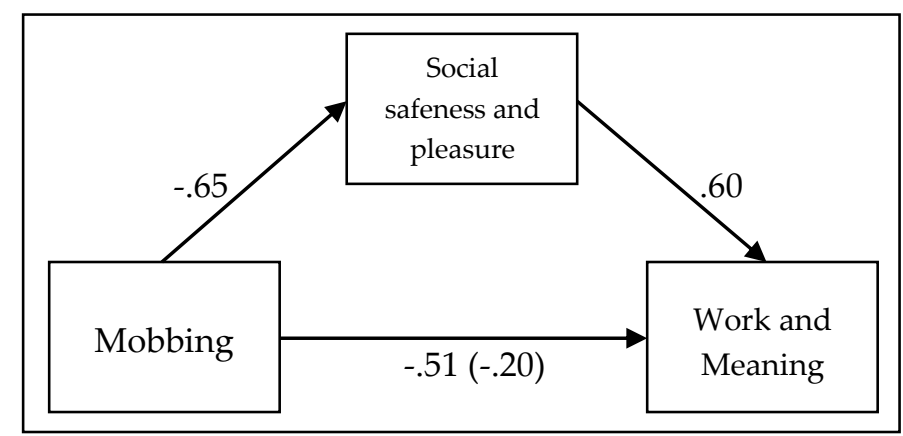

Figure 1. Mediator Role of Social Safeness and Pleasure in the Correlation between Mobbing and Meaning of Work

As seen in the Figure 2, the effect of mobbing on the meaning of work is found $(\beta=-.51)$ according to the result of stepwise regression analysis. When mediator element (social safeness and pleasure) is added to the analysis, $\beta$ value is decreased to $(\beta=-.20)$. In this context, it can be said that social safeness and pleasure has a mediating role in the correlation between mobbing and meaning of work. In the last analysis, because the effect of independent element (mobbing) is not totally cleared away, this situation is the sign of other mediator variables (Baron \& Kenny, 1986; Kenny, Kashy, \& Bolger, 1998; Kenny et al., 2003). Therefore, social safeness and pleasure is a "partially mediator variable" in the link between mobbing and meaning of work.

Finally, Sobel test is applied to make sure that social safeness and pleasure is a partially mediator variable in the link between mobbing and meaning of work. Sobel test is used to analyze the significance level of decrease in beta values with extensive sampling and normal distribution (Preacher \& Kelley, 2011; Wiedermann \& Von Eye, 2015). Sobel test result, related to the show of mediating role of the social safeness and pleasure, $Z$ value is calculated as significant at $p<.001$ level $(Z=-10.3367896 ; p=.00)$. In other words, social safeness and pleasure is proved statistically to be the mediator in the relationship between mobbing and meaning of work. 


\section{Discussion, Conclusion, and Suggestions}

The basic aim of this current study is to control the mediating role of social safeness and pleasure in the relationship between the meaning of the work and mobbing in academicians in 58 different education faculties. The findings of our study confirm that there are associations between mobbing, meaning of the work and social safeness and pleasure. According to the mediating analysis findings, social safeness and pleasure are the partial reason for the relationship between mobbing and meaning of the work. As the mobbing level increases, the social safeness and pleasure decrease and this decrease also lower the individuals' meaning of work. On the other hand, as the mobbing decreases in the work place, the social safeness and pleasure levels of individuals increase and this increment positively affects the perception levels of individuals related to the meaning of the work. In literature, there is no such study which examines the relationship between these three concepts. Therefore, we had three hypotheses in order to reach the three goals of this study.

According to the first hypothesis of the study, mobbing negatively affects the social safeness and pleasure. Our results indicate that mobbing negatively influences the level of social safeness and pleasure. In previous studies, there was no study which directly examined the association between the mobbing and the social safeness and pleasure. However, Kelly et al. (2012) showed that social safeness and pleasure occurred as a response to the friendship and partnership relationships. According to Gilbert (2010), social safeness and pleasure were negatively associated with hostility. When it is considered that mobbing is composed of hostile attitudes and behaviors in the work place, it is normal that one does not to have feelings of social safeness and pleasure. Moreover, Cemaloğlu and Kılınç (2012) stressed that mobbing has direct negative impact on organizational trust. Thus, the statements, which are mentioned above, are in line with our findings.

According to the second hypothesis of the study, social safeness and pleasure positively affect the meaning of the work. Our findings show that social safeness and pleasure positively influence the meaning of the work. Although there is no such study which was related directly to the association between these two concepts, few studies mentioned about this relation, implicitly. For example, Akın's (2015) research result revealed an important negative link between organizational cynicism and organizational trust (in the view of social safeness and pleasure) levels. He also said organizational cynicism and organizational mistrust had unfavorable effect on workers' performance. Besides, Fard and Karimi (2015), Ajayi et al. (2011), and Tekingündüz, Top, Tengilimoğlu, and Karabulut (2015) underlined that organizational trust contribute to jobsatisfaction and job performance. On the other hand, there are some other studies which claim that social safeness and pleasure are positively associated with life satisfaction, meaning of the life, life quality, flourishing, authentic living and extraversion (Satici, Uysal, \& Akin, 2013; Uysal, 2015a, 2015b). Therefore, these statements support our findings. In this regard, the second hypothesis is also confirmed.

In the third and the last hypothesis, we believed that mobbing negatively influenced the meaning of the work. Our findings show that mobbing has an adverse effect on the meaning of the work. Yaman and Sariçam (2015) detected that there was a negative relationship between the mobbing and the meaning of the work. Furthermore, there are studies which claim that the work performance, work satisfaction and organizational trust of individuals who were exposed to mobbing were negatively affected (Carroll \& Lauzier, 2014; Çivilidağ \& Sargın, 2013; Estes \& Wang, 2008; Harvey, Heames, Richey, \& Leonard, 2006; Lutgen-Sandvik, 2003; Mathisen, Einarsen, \& Mykletun, 2008; Yaman, 2007, 2008, 2009, 2010; Yaman, Vidinlioğlu, \& Çitemel, 2010; Zapf, Knorz, \& Kulla, 1996). These statements support the results of our study. Thus, the last hypothesis is also confirmed. Conclusively, our study reached its goal since all three hypotheses were confirmed. 
There are some limitations in the study. First of all, measurement tools are the scales which are used for the self-assessment. Since mobbing can undermine the corporate identity, individuals had hesitations while answering the questions of measurement tools. This limitation was tried to be eliminated by creating the link. However, this led to different limitations such as trueness. The second limitation was that the study group was limited with the academicians in the faculties of education. In future studies, it will be beneficial to create a study group which will be composed of academicians from different faculties of all universities in Turkey. We considered that social safeness and pleasure were the only factor which led to the relationship between mobbing and meaning of the work. This was the last limitation of the study. Future studies can be performed by adding different parameters of mediators.

If the employer fails to provide an efficient, productive and peaceful work environment, the costs occurring at the individual and organization level will increase and keep increasing. Therefore, in each of the institutions, precautions should be taken against mobbing which corrupts the meaning of the work for employee and makes the work meaningless. Work place support units (which are focused on the development of peace and the culture of the institution) should be either established or activated in the work place. Even though the mobbing is not prevented in the work place, the social safeness and pleasure of individuals will be positively affected; therefore, meaning of the work will increase. 


\section{References}

Ajayi, I. A., Awosusi, O. O., Arogundade, B. B., \& Ekundayo, H. T. (2011). Work environment as correlate of academic staff job performance in South West Nigeria Universities. European Journal of Educational Studies, 3(1), 1-9.

Akın, U. (2015). The relationship between organizational cynicism and trust in schools: A research on teachers. Education and Science, 40(181), 175-189. doi:10.15390/EB.2015.4721

Akın, A., Hamedoğlu, M. A., Kaya, Ç., \& Sarıçam, H. (2013). Turkish version of the Work and Meaning Inventory (WAMI): Validity and reliability study. The Journal of European Education, 3(2), 11-16.

Akın, A., Uysal, R., Özkara, N., \& Bingöl, T. Y. (2012, September 13-15). The validity and reliability of the Turkish version of the Social Safeness and Pleasure Scale (SSPS). Paper presented at Applied Education Congress, METU, Ankara, Turkey.

Archibong, I. A., Bassey, A. O. G., \& Effiom, D. O. (2010). Occupational stress sources among university academic staff. European Journal of Educational Studies, 2(3), 217-225.

Baron, R., \& Kenny, D. (1986). The moderator-mediator variable distinction in social psychological research: Conceptual, strategic, and statistical considerations. Journal of Personality and Social Psychology, 51, 1173-1182.

Bartholomew, K., \& Horowitz, L. M. (1991). Attachment styles among young adults: A test of a fourcategory model. Journal of Personality and Social Psychology, 61, 226-244.

Baumeister, R. F., \& Leary, M. R. (1995). The need to belong: Desire for interpersonal attachments as a fundamental human motivation. Psychological Bulletin, 117, 497-529.

Baumeister, R. F., \& Tice, D. M. (1990). Anxiety and social exclusion. Journal of Social and Clinical Psychology, 9, 165-195.

Bowlby, J. (1982). Attachment and loss: Retrospect and prospect. American Journal of Orthopsychiatry, $52,664-678$.

Browne, M. W., \& Cudeck, R. (1993). Alternative ways of assessing model fit. In K. A. Bollen, \& J. S. Long, (Eds.), Testing Structural Equation Models (pp. 136-162). Beverly Hills, CA: Sage.

Cabaros, M. A., \& Rodrigues, P. V. (2006). Psychological harassment in the Spanish Public University System. Academy of Health Care Management Journal, 2, 21-39.

Carroll, T. L., \& Lauzier, M. (2014). Workplace bullying and job satisfaction: The buffering effect of social support. Universal Journal of Psychology 2(2), 81-89. doi:10.13189/ ujp.2014.020205

Cemaloğlu, N., \& Kılınç, A. Ç. (2012). The relationship between school principals' ethical leadership behaviors and teachers' perceived organizational trust and mobbing. Education and Science, 37(165), 137-151.

Çivilidağ, A., \& Sargın, N. (2013). Academics' mobbing and job satisfaction levels. The Online Journal of Counseling and Education, 2(2), 55-66.

Çolak, I., Altinkurt, Y., \& Yilmaz, K. (2014). The relationship between teachers' teacher leadership roles and organizational commitment levels. Educational Process: International Journal, 3(1-2), 35-51.

Dennett, D. (1995). Darwin's Dangerous Idea: Evolution and the Meanings of Life. New York, NY: Simon and Schuster.

Davenport, N., Distler, S. R., \& Eliot, G. (1999). Mobbing emotional abuse in the American Workplace. Ames, Iowa: Civil Society Pub.

Erkutlu, H., \& Chafra, J. (2014). Ethical leadership and workplace bullying in higher education. Hacettepe University Journal of Education, 29(3), 55-67.

Estes, B., \& Wang, J. (2008). Workplace incivility: Impacts on individual and organizational performance. Human Resource Development Review, 7(2), 218-240. doi:10.1177/1534484308315565 
Fard, P. G., \& Karimi, F. (2015). The relationship between organizational trust and organizational silence with job satisfaction and organizational commitment of the employees of university. International Education Studies, 8(11), 219-227. doi:10.5539/ies.v8n11p219

Fogg, P. (2008). Academic bullies. Chronicle of Higher Education, 55(3), B10.

Frankl, V. E. (2014). The Will to Meaning: Foundations and Applications of Logotherapy. New York: New American Library (Penguin Group).

Frankl, V. E. (2006). Man's Search for Meaning. Boston: Beacon Press. Original version published in 1959.

Friedenberg, J. (2008). The Anatomy of an Academic Mobbing. Florida: The Edwin Mellen Press.

Fryer, D. M., \& Payne, R. L. (1984). Pro-active behaviour in unemployment: Findings and implications. Leisure Studies, 3, 273-295.

Gilbert, P. (2005). Compassion and cruelty: A biopsychosocial approach. In P. Gilbert (Ed.), Compassion: Conceptualisations, Research, and Use in Psychotherapy (pp. 1-74). London: Routledge.

Gilbert, P. (2009). Moving beyond cognitive behaviour therapy. The Psychologist, 22, 400-403.

Gilbert, P. (2010). Compassion Focused Therapy: Distinctive Features. London: Routledge.

Gilbert, P., McEwan, K., Mitra, R., Franks, L., Richter, A., \& Rockliff, H. (2008). Feeling safe and content: A specific affect regulation system? Relationship to depression, anxiety, stress, and selfcriticism. The Journal of Positive Psychology, 3, 182-191. doi:10.1080/17439760801999461

Gilbert, P., McEwan, K., Mitra, R., Richter, A., Franks, L., Mills, A., ... Gale, C. (2009). An exploration of different types of positive affect in students and patients with bipolar disorder. Clinical Neuropsychiatry, 6(4), 135-143.

Gül, H., İnce, M., \& Özcan, N. (2011). The relationship between workplace mobbing and burnout among academics at a Turkish University. Research Journal of International Studies, 18, 118-134.

Harvey, M. G., Heames, J. T., Richey, R. G., \& Leonard, N. (2006). Bullying: From the playground to the boardroom. Journal of Leadership and Organizational Studies, 12(3), 1-11. doi:10.1177/107179190601200401

Hu, L. T., \& Bentler, P. (1995). Evaluating model fit. In R. H. Hoyle (Ed.), Structural Equation Modeling: Concepts, Issues, and Applications (pp. 76-99). London: Sage.

Kartal, S. E. (2016). Determining school administrators' perceptions on institutional culture: A qualitative study. Educational Process: International Journal, 5(2), 152-166. doi:10.12973/edupij.2016.52.6

Kaya, Y. K. (1993). Eğitim yönetimi, kuram ve Türkiye'deki uygulamalar. Ankara: Set Ofset Matbaacıllk.

Keashly, L., \& Neuman, J. (2010). Faculty experiences with bullying in higher education. Administrative Theory \& Praxis, 32(1), 48-70. doi:10.2753/ATP1084-1806320103

Kelly, A. C., Zuroff, D. C., Leybman, M. J., \& Gilpert, P. (2012). Social safeness, received social support, and maladjustment: Testing a tripartite model of affect regulation. Cognitive Therapy and Research, 36(6), 815-826. doi:10.1007/s10608-011-9432-5

Keltner, D. (2009). Born to be good: The science of a meaningful life. New York, NY: Norton.

Kenny, D. A., Kashy, D., \& Bolger, N. (1998). Data analysis in social psychology. In D. Gilbert, S. Fiske, \& G. Lindzey (Eds.), Handbook of social psychology (4th ed., pp. 233-265). New York: McGraw-Hill.

Kenny, D. A., Korchmaros, J. D., \& Bolger, N. (2003). Lower level mediation in multilevel models. Psychological Methods, 8(2), 115-128.

Khoo, S. B. (2010). Academic mobbing: Hidden health hazard at workplace. Malaysian Family Physician, 5(2), 61-67.

Leymann, H. (1996). The content and development of mobbing at work. European Journal of Work and Organizational Psychology, 5(2), 165-184. 
Lips-Wiersma, M., \& Morris, L. (2009). Discriminating between meaningful work and the management of meaning. Journal of Business Ethics, 88(3), 491-511. doi:10.1007/s10551-009-0118-9

Lutgen-Sandvik, P. (2003). The communicative cycle of employee emotional abuse: Generation and regeneration of workplace mistreatment. Management Communication Quarterly, 16(4), 471-501. doi:10.1177/0893318903251627

MacKinnon, D. P. (2008). Introduction to statistical mediation analysis (Multivariate Applications Series). Lawrence Erlbaum: New York.

MacKinnon, D. P., Warsi, G., \& Dwyer, J. H. (1995). A simulation study of mediated effect measures. Multivariate Behavioral Research, 30(1), 41-62.

Mathisen, G. E., Einarsen, S., \& Mykletun, R. (2008). The occurrences and correlates of bullying and harassment in the restaurant sector. Scandinavian Journal of Psychology, 49(1), 59-68. doi:10.1111/j.1467-9450.2007.00602.x

Molden, D. C., \& Dweck, C. S. (2006). Finding "meaning" in psychology. American Psychologist, 61(3), 192-203. doi:10.1037/0003-066X.61.3.192

Molden, D. C., \& Dweck, C. S. (2000). Meaning and motivation. In C. Sansone \& J. M. Harackiewicz (Eds.), Intrinsic and Extrinsic Motivation: The Search for Optimal Motivation and Performance (pp. 131159). San Diego, CA: Academic Press.

Morin, E. (2008). The meaning of work, mental health and organizational commitment (Report R-585). Psychological Health Studies and Research Projects.

Moayed, F. A., Daraiesh, N., Shell, R., \& Salem, S. (2006). Work place bullying: A review of risk factors and outcomes. Theoretical Issues in Ergonomics Science, 7(2), 311-327. doi:10.1080/14639220500090604

Park, C. L., \& Folkman, S. (1997). Meaning in the context of stress and coping. Review of General Psychology, 1, 115-144.

Ryan, R. M., \& Deci, E. L. (2000). Self-determination theory and the facilitation of intrinsic motivation, social development and well-being. American Psychologist, 55(1), 68-78.

Pickett, C. L., Gardner, W. L., \& Knowles, M. (2004). Getting a cue: The need to belong and enhanced sensitivity to social cues. Personality and Social Psychology Bulletin, 30(9), 1095-107. doi:10.1177/0146167203262085

Preacher, K. J., \& Kelley, K. (2011). Effect size measures for mediation models: Quantitative strategies for communicating indirect effects. Psychological Methods, 16(2), 93-115. doi:10.1037/a0022658

Satici, S. A., Uysal, R., \& Akin, A. (2013). Authenticity as a predictor of social safeness in Turkish university students. Ceskoslovenska Psychologie, 57(6), 533-541.

Steger, M. F., Dik, B. J., \& Duffy, R. D. (2012). Measuring meaningful work: The Work and Meaning Inventory (WAMI). Journal of Career Assessment, 20(3), 322-337. doi:10.1177/1069072711436160

Taylor, S. K. (2012). Workplace bullying in higher education: Faculty experiences and responses. (Doctoral dissertation). University of Minnesota. Retrieved from http://purl.umn.edu/127285

Tekingündüz, S., Top, M., Tengilimoğlu, D., \& Karabulut, E. (2015). Effect of organisational trust, job satisfaction, individual variables on the organisational commitment in healthcare services. Total Quality Management \& Business Excellence, 1-20. doi:10.1080/14783363.2015.1099428

Tinaz, P. (2006). İşyerinde psikolojik taciz. İstanbul: Beta Basım Yayım.

Uysal, R. (2015a). Five factor personality as the predictor of social safeness. Mevlana International Journal of Education (MIJE), 5(2), 31-39. doi:10.13054/mije.14.89.5.2

Uysal, R. (2015b). The predictive roles of social safeness and flourishing on problematic Facebook use. South African Journal of Psychology, 45(2), 182-193. doi:10.1177/0081246314560010

Westhues, K. (1998). Eliminating Professors: A Guide to the Dismissal Process. Lewiston, NY: The Edwin Mellen Press. 
Westhues, K. (2004). Workplace Mobbing in Academe: Reports from Twenty Universities. Lewiston, NY: The Edwin Mellen Press.

Westhues, K., (2006). The Remedy and Prevention of Mobbing in Higher Education: Two Case Studies. Lewiston, NY: The Edwin Mellen Press.

Wiedermann W., \& Von Eye, A. (2015). Direction of effects in mediation analysis. Psychological Methods, 20(2), 221-244. doi:10.1037/met0000027

Yalom, I. D. (1980). Existential psychotherapy. New York: Basic Books.

Yaman, E. (2007). Üniversitelerde bir eğitim yönetimi sorunu olarak öğretim elemanının maruz kaldiğı informal cezalar: Nitel bir araştırma [The informal punisments, to which the academic staff is subjected, as an education management problem in universities: A qualitative research] (Unpublished doctoral dissertation). Marmara University, Institute of Educational Sciences, İstanbul.

Yaman, E. (2008). Üniversiteler ve etik: Baskılar ya da psikolojik şiddet. İş Ahlâkı, 1, 81-97.

Yaman, E. (2009). The validity and reliability of the Mobbing Scale (MS). Educational Sciences: Theory E Practice, 9(2), 967-988.

Yaman, E. (2010). Perception of faculty members exposed to mobbing about the organizational culture and climate. Educational Sciences: Theory \& Practice, 10(1), 547-578.

Yaman, E., \& Sarıçam, H. (2015). Psikoşiddetin iş anlamına etkisi. E-AJELI (Anatolian Journal of Educational Leadership and Instruction), 3(2), 16-26.

Yaman, E., Vidinlioğlu, Ö., \& Çitemel, N. (2010). İşyerinde psiko-şiddet, motivasyon ve huzur: Öğretmenler çok şey mi bekliyor? Psiko-şiddet mağduru öğretmenler üzerine. Uluslararası İnsan Bilimleri Dergisi, 7(1), 1136-1151.

Yelgecen Tigrel, E., \& Kokalan, O. (2009). Academic mobbing in Turkey. International Journal of Social, Behavioral, Educational, Economic, Business and Industrial Engineering, 3(7), 1473-1481.

Zapf, D., Knorz, C., \& Kulla, M. (1996). On the relationship between mobbing factors, and job content, social work environment, and health outcomes. European Journal of Work and Organizational Psychology, 5(2), 215-238. 